\title{
Legal Standing of Absenteeism (Afwezigheid) to the Guarantee of Civil Rights Protection
}

\author{
Efraim Tana*, Anwar Borahima, Nurfaidah Said, Winner Sitorus \\ Faculty of Law, Hasanuddin University, South Sulawesi, Indonesia \\ ${ }^{*}$ Corresponding author
}

\begin{abstract}
The research aims to analyze and find out the legal standing of absenteeism (afwezigheid) to the guarantee of civil rights protection in Indonesia. The research is a normative legal research by using a statute, conceptual and philosophical, and comparative approaches. The results show that the essence of absenteeism (absentee dominii) is a guarantee of legal protection certainty against the inability of legal subjects to attend when expected. Legal protection certainty can occur because of the presence of representatives based on court decisions. The implementation of absenteeism regulations includes regulations that are not in sync with higher regulations, namely, the regulation of the Minister of Finance (PMK) on the settlement of Chinese foreign assets. This PMK is still implemented by taking advantage of the unsynchronized regulations. There are also regulations which are equivalent but can be implemented by applying the legal principle lex specialis derogat legi generali. The management of absenteeism is carried out through publicity and supervision carried out by the Attorney General, BPK and tiered supervision within the Ministry of Law and Human Rights of the Republic of Indonesia. Management until the 30-year expiration period is a form of legal protection for civil rights for absentees.
\end{abstract}

Keywords: Absenteeism; Civil Rights; Land; Legal Protection

DOI: $10.7176 / \mathrm{JLPG} / 102-09$

Publication date:October $31^{\text {st }} 2020$

\section{Introduction}

Explicitly, the consequence of Indonesia has been declared as a constitutional State, certainly for all actions must be based on law both written and unwritten. For society, the purpose of law is to achieve a legal balance between rights and obligations that are aligned with the values that live in society, so that order in society can be realized in accordance with the development of a sense of community justice, because what is good and fair is the law of law (equum et bonum est lex legum). ${ }^{1}$

As a guarantee of legal purposes, then the rights and obligations must be explicitly stated in the constitution or law to ensure legal certainty. ${ }^{2}$ Laws must be arranged in a hierarchical manner and should not conflict with each other. The hierarchical structure of statutory regulations starts from ground norms as basic norms to activate the norms underneath; it means that every law in a country must come from a basic law (ground norms) namely the constitution. ${ }^{3}$ A good constitution is a synchronous and harmonious constitution. Synchronization is performed in each statutory regulation so that it does not conflict with each other, both hierarchically and horizontally, in order to guarantee legal certainty.

The 1945 Constitution of the Republic of Indonesia ${ }^{4}$ provides guarantees of legal certainty in protecting property rights for citizens. There is property rights recognition that cannot be taken over arbitrarily. Compensation for property rights, even though they are used for public purposes. Property rights are recognition from the State or persons against the owner of the property, as evidenced by proof of ownership. Property rights can be owned by both individuals and legal entities. ${ }^{5}$

As the owner of the property, only the owner has the right to transfer ownership rights to another person. The recognition of property rights is a guarantee of legal certainty so that people or even state legal entities may not act arbitrarily to take by force and even illegally control someone' property. Property rights are an inseparable unit because their property rights are still attached to the object (droit de suite), ${ }^{6}$ so that an object can be retained from

1 Amir Ilyas et al. (2006). Kumpulan asas-asas hukum, Jakarta: PT. RajaGrafindo Persada, p. 105.

2 Krishna, V. V., Kubitza, C., Pascual, U., \& Qaim, M. (2017). Land markets, property rights, and deforestation: insights from Indonesia. Journal World Development, Vol. 99, 335-349.

3 Fuady, M. (2013). Teori-Teori Besar Dalam Hukum (Grand Theory), Jakarta: Prenadamedia Group, p. 142

4 Article 28H Paragraph (4) the 1945 Constitution states that every person has the right to own private property and these rights cannot be taken over arbitrarily by anyone.

5 Irwansyah. (2020). Kajian Ilmu Hukum, Yogyakarta: Mirra Buana Media, p. 43.

6 Droit de suite (Perancis), is characteristics of material rights, namely a right that continues to follow the owner of the 
anyone, ${ }^{1}$ even though the owner of the right has died or the right owner is in an absence condition (afwezigheid).

The interest of someone in absenteeism must be protected both by law and the State, because he still has the status of a legal subject. Absenteeism does not kill the civil rights of a person whose interest is in uncertainty. Therefore, for legal certainty need a hierarchical, consistent arrangement in an effort to protect the rights of everyone even in absenteeism, so that there should be no arbitrariness in having the right of the absenteeism person including the State to control it.

In fact, that someone is in absenteeism (afwezigheid), the interested parties do not submit a request to the court. The assets of the person in absenteeism are controlled and managed or owned without a court order to administer and represent the absent person. The arrangement of absenteeism were clear but were reluctant to be implemented. This can be seen in the following arrangements: 1. Ex-Dutch foreign-owned assets, 2. Ex-Chinese foreign-owned assets, and 3. management of fund transfers.

The arrangement of absenteeism regulations above, there is not require court ruling as regulated in Article 463 B.W, so that each regulation on absenteeism has its own management. As a result, there can be egos by sector of each absenteeism institution and without clear indicators, fighting over authority, so that it does not guarantee legal protection to those who are absent.

The unclear whereabouts of a person can be seen from the news media. Objects or properties of the absent person can become fight. The struggle for control is done by citizens as well as by the State through state organs, ${ }^{2}$ for example the National Land Agency controls Ex-Dutch Foreign-owned assets. ${ }^{3}$ What do you want to do with the money without the owner? ${ }^{4}$ and etc.

On the one hand, the forms of the absence of empirical facts can be someone who has gone abroad with no more news, a person who has lost due to mental illness so that he cannot return to his place of residence, or lost due to a plane crash, ship accident, nature disaster, war, even riots, and so on, even though their whereabouts are unknown, their property is still protected. ${ }^{5}$ On the other hand, there are several institutions that manage assets that are absent and various bases for their regulation must have their own mechanisms for managing them. Each absenteeism institution feels entitled, regardless of the core of service institution that was established since its inception, namely the Heritage Hall to solve the problem of absenteeism.

\section{Method}

The research is a normative legal research by using a statute, conceptual and philosophical, and comparative approaches. ${ }^{6}$ It focuses on the construction of positive legal norms, namely to examine and analyze in depth the relationship between the problem under study and the underlying theories and the principles of legislation on absenteeism (afwezigheid).

\section{A Concept of Absenteeism in a Civil Law Perspective}

Absenteeism is a concept, not only in the field of legal knowledge but also in social knowledge. Certainly, it becomes a question mark, what is the meaning of the concept of absenteeism in the two fields, namely the social and legal fields. Absenteeism in the field of social science is different from that in the field of law. Absenteeism is placed in the field of law because it is a rule as written law or positive law that binds and regulates everyone, when experiencing absenteeism.

The concept of absenteeism in the field of law is derived from the word in absentia (Latin), also means absence, but the concept of in absentia/afwezigheid is known in the aspect of criminal. The state of absenteeism from the legal field should also be able to distinguish between absenteeism from State, criminal and civil administration. There must be a symbol or language that can differentiate (afwezigheid/absentia) or which absenteeism is meant. The researcher wants to reintroduce the types of afwezigheid/absentia as a differentiator between absenteeism and

object, or a right that follows the object in the hands of anyone. Droit de suite memiliki arti "right to follow": "The droit de suite literally translated as the right to follow, "Black's Law Dictionary $9^{\text {th }}$ Edition Law Encyclopedia, p. 570

1 Sofwan, S.S.M. (2008). Hukum Perdata: Hukum Benda, Yogyakarta, Liberty, p.24

2 Liputan 6, "Uang Tak Bertuan Bisa Disita Negara", (on line) accessed on 24 September 2018.

3 CNN Indonesia, "Uang Elektronik Hilang, Dana Tak Bisa Kembali" (on line) accessed on 18 December 2018.

4 Kalimantan Bisnis.Com, 02 Februari 2018 02:00 WIB, “Duit Tak Bertuan, Mau Diapakan?”, (on line) accessed on 25 September 2018.

5 Sri Susyanti Nur, (2015). Aspek Hukum Pendaftaran Tanah Bekas Milik Asing sebagai Aset Pemerintah Daerah. Hasanuddin Law Review, 1(1), 87-100. doi: http://dx.doi.org/10.20956/halrev.v1i1.42.

6 Marzuki, P.M. (2011). Penelitian Hukum, Jakarta: Kencana Prenada Media Group, p.35 
another or by their meaning.

A person before experiencing his absenteeism may own property or have had a legal relationship with another party, whether he is a debtor or creditor. For example, before a person is declared missing, he has had a legal relationship in the form of a lease. The absent person' house is rented out to someone for a certain period of time. When it ended and the lessee want to continue the lease extension. However, the lessee can no longer find the owner of the house, or any heirs. The lessee loses information about the whereabouts of the owner. How is the civil rights of the absent person on his house? In civil law there is absenteeism, which provides a description of the condition of a person who has left his place of residence for a relatively long period of time, without any power being given to manage his interests and assets. ${ }^{1}$

Researchers argue that absenteeism requires regulation. Regulations are needed because there is no power or representative to manage the assets of the absent person. It seems that the right of the absent person will be exercised if there is power left by the absent person. But then it will become a problem when the power left behind is no longer valid. When there is no power there arises absence. The concept of absence in civil law is called Absentee Dominii [in Latin]. Absentee means absenteeism and Dominii means ownership or property rights. So, Absentee Dominii is the ownership right in the name of the unknown owner.

Every person who is incompetent must have a representative appointed by the court to carry out the affairs and interests of the person represented. The actions of an incompetent person' representative become lawful, when carried out by a representative appointed by the court. From the point of view of the representative as executor of legal interests and fiction, absenteeism can constitute legal incompetence if he is in incapacity from the start. ${ }^{2}$ However, in absence they can also be competent but do not have the right to be authorized because of physical absence or cannot be present when needed. Due to physical absence, the right to be authorized must be represented based on a court order. The incompetence of a legal subject, apart from being determined by law, is also determined by court decisions.

Absenteeism is not the authority that was agreed upon, nor is it voluntary handling (zaakwarneming) nor it is not a relinquishment of rights (rechtsverwerking) so as to transfer the absentee ownership rights. However, in absenteeism, there must be a representative based on a court order to take care of the absentee interests, so that the transfer of rights can be carried out to the interested party, except for the wife who will terminate the marital relationship with her husband as the absent person.

\section{Synchronization of Absenteeism Arrangements}

A situation or condition of someone whose whereabouts are not known, gives an opportunity to the parties concerned, whether it is family, parties related to the absent person, even the Attorney General' Office to be able to demand obligations from the absent person. The existence of a prosecutor in this situation is an exclusive matter. Herein lies the problem in the category of relations, an event that raises the problem of how to demand the absent person to do his obligations. These events rarely occur but are quite confusing to resolve, especially if the heirs are unknown.

A result of research showed that it is not difficult if the absent person has an heir, because of the principle of le mort saisit le vif, so that the assets of the absent person can move immediately, including the obligation of the absent person, ${ }^{3}$ is carried out by the heir. However, it will be difficult when the absent person and their heirs are unknown. Those who control the asset of absent person due to lease, they can only ignore it and wait until the absent person or his heir appears, without a clear certainty of time. The principle of nemo dat quoad non habet provides a limitation so that the party who controls the asset of the absent person, even the heir, cannot immediately claim to be his own, but must go through a mechanism determined by law. ${ }^{4}$

In the context of land, the absent land owner will be questioned where the heirs are. If then the heir appears and is able to show old evidence, it is possible to be registered again. But it becomes a problem in itself, when the heirs have occupied the land for generations and suddenly they are taken over by the owner of the capital, just because they are not registered. This is rape justice. Not registering his land is not a serious crime so it must be evicted, expelled from his own land.

1 Nugroho, B.D. (2017). Hukum Perdata Indonesia, Integrasi Hukum Eropa Kontinental Ke Dalam Sistem Hukum Adat dan Nasional, Bandung: PT Refika Aditama, p. 32.

2 Since the beginning, the legal subject was in a state of insanity, so that it was put under interdiction and then lost.

$3 \mathrm{Ibid}$.p. 84. It is also in line with Article 846 B.W, the inheritance must be divided among the heirs, so that the heirs can claim their rights.

4 Bakker, L., \& Moniaga, S. (2010). The space between: Land claims and the law in Indonesia. Asian Journal of Social Science, 38(2), 187-203. 
The protection provided is certainly not the same as land that has been registered. Registered is means that the ownership rights are exercised according to law so that the state is obliged to provide protection. Certificate is proof of ownership, accessible in the sense that it can be used as collateral. Whereas land that has been controlled by the population from generation to generation cannot be used as collateral, but the state still provides protection because of the citizens themselves, not their ownership rights. If they live on land owned by others, of course the role of the state is to resolve and provide protection to those who have rights.

Land that is directly controlled by the State or falls to the State tends to be a target by certain individuals. These lands are widely used by mafia or land speculators, by approaching the rulers and easily obtaining permits. So it is not surprising that we can see magnificent buildings of capital owners standing in the middle of the city. The building of the capital owner located in the middle of the city should reasonably be suspected of originating from land that was previously owned by someone, but due to law or not being converted, the land has fallen to the state, or their heirs no longer have authentic documents, so they cannot again owning land.

Furthermore, in the context of banking, fund transfers are not always as smooth as imagined. It turns out that in the implementation there are problems when the sender and receiver do not come to collect the funds that have been transferred, even when they are returned to the sender, they do not come to collect them. What is the status of the funds that are not taken? Obviously, these funds do not belong to the bank. The fund belongs to the customer and his/her rights to the fund will be protected. Who has an interest in the funds deposited in the bank?

The use of electronic media can cause problems so that regulations are needed to ensure the security of the smooth running of funds transfer transactions and guarantee certainty for parties involved in carrying out fund transfer activities. Problems that occur must be handled properly, so that the implementation of fund transfers can be carried out safely, smoothly, without causing problems. Fraud through technological information media, such as Whatssapp, Short Message Service, Website Fraud cannot occur. However, this research was not focused on fraud but focused on the absence where the recipient and sender of money were sought but came to collect their funds because their whereabouts were unknown.

Technological findings always have a significant influence on facilitating human work, one of which is the internet media. Although it cannot be denied that technological advances can be misused by certain individuals. This finding then develops in the business world which is used by institutions or companies as a fund transfer activity.

Funds transfer activities can be carried out by institutions, either banks or non-banks to transfer funds. In principle, there are three parties that play an important role in transferring funds, namely: the sending party, the receiving party and the operator party. These three parties are involved in a series of activities starting with an order from the originator which aims to transfer an amount of funds to the receiving party stated in the Funds Transfer Order until the fund is received by the receiver. Sending party is an originator, executing originator, and all next executors issuing a funds transfer order. Receiving party is the party named in a funds transfer order to receive funds resulting from a transfer.

In cash transfer transactions, it turns out that there are parties who do not come to take or claim the funds addressed to him, and when they are returned to the sender, the sender does not come to collect them. It feels strange or suspicious because the person who got the money sent did not come to collect it.

In fund transfer activities, only cash transfers are clearly regulated. Arrangements that have been taken into account when cash is sent, not taken by the recipient and the sender back. When the funds transferred are not taken, then the fund is no owner, meaning that the owner of the transferred funds is no longer known.

According to Doeljono, ${ }^{1}$ it is very interesting that Singapore also has rules governing absenteeism. When an Indonesian citizen dies and his heir is unknown, the Singapore government will notify the Indonesian government to immediately take the property or assets of Indonesian person. This is a rule of high moral spirit, which upholds private property rights in Singapore. Doeljono continued, that KPK wanted to hand over the proceeds of the corruptor' crimes to Balai Harta Peninggalan (BHP), but was rejected by the Ministry of Law and Human Rights by a reason that the corruptors were present and their whereabouts were still known, so it did not fulfill the element of absenteeism.

It is interesting to examine why so much money is not claimed by the owner, even though when it is want to be sent, the data of the sender and recipient are very complete because they are equipped with personal identification and mobile phone, in order to get the Transaction Center Number (NPT) sent via Sort Messages Service (SMS) to recipients and the nominal amount sent.

1 KaSubdit the Heritage Hall and State Curator, the Meeting Result for all Indonesia held on Bintaro 20-22 October 2019. 
According to Edi Hadyanto, ${ }^{1}$ this is indeed surprising, the identity is complete, the notification to the recipient has been sent via SMS or email, but the person concerned still does not come to take it. This is a big question mark, because these cash transfer funds can be suspected of being the result of money laundering crimes or funds to finance crimes, such as terrorists. Certainly, the e-money operator should also comply with the provisions, if the card is lost and there are still funds remaining in it, the funds should be submitted to BHP.

According to the researcher, it seems that the development of absenteeism has varied. In B.W, which regulates absenteeism requires a court ruling, but for the Funds Transfer Law does not require a court ruling, so it appears that the regulations governing absenteeism are not harmonious. As a result, doubts arose on the part of the asset manager who did not attend, whether the delivery of funds whose existence was unknown had to go through a stipulation or not. However, in fact, on a case-by-case basis, it can be resolved by synchronizing the principles of law, so there is no need to argue again. The legal principle of lex specialist derogat legi generali can be applied.

According to the researcher, this is to anticipate if there is a transfer of funds with a small amount of funds. The value of the funds is small if want to use a court order, the funds may run out or not be sufficient to pay court fees. Furthermore, in order to increase the compliance of administrators with regulatory provisions, a supervisory role is needed, namely the Financial Services Authority (OJK). The goal is to settle transfer funds to a deposit account that is not taken by the recipient and the sender. In order not to burden the deposit account, it is immediately submitted to BHP. It also appears that movable property still refers to B.W and movable property in the form of money can be regulated by the Funds Transfer Law, immovable assets do not require a court ruling.

\section{Problems in Legal Regulations of Absenteeism at Practical Level}

In 1959 the Government of Indonesia issued Presidential Regulation No. 10 of 1959 dated 16 November 1959. This Presidential Regulation was called the "Regulation of Small and Medium Traders" or simply "P.P.K.E" (Peraturan Pedagang Kecil dan Eceran), which came into effect on the day it was enacted and had retroactive power until 10 July 1959. ${ }^{2}$ This Presidential Regulation was born with a prohibition based on a letter Decree of the Minister of Trade dated 14 May 1959 No. 2933/M. ${ }^{3}$ The essence of this Presidential Regulation contains the prohibition of foreigners doing business in retail trade at the district level and below (outside the regional capital city) and the obligation to transfer their business to Indonesian citizens.

This regulation has become controversial, so that in a number of regions even physical racial clashes occur. Not a few citizens of Chinese descent (non-Indonesian citizens) have returned to their home countries. The exodus was massive. There are 102 thousand transported to China using ships sent by Chinese government. ${ }^{4}$ When there is an exodus of immovable property, it is simply abandoned and becomes a treasure of absence.

It is a historical fact that we all know that the role of the Indonesian Communist Party had a major influence on politics in Indonesia in the 1950s era. The Indonesian Communist Party was formed on 23 May 1929. On 30 September 1965, a movement called G30 S/PKI, which brutally murdered Generals and dumped their bodies in a crocodile hole. The deaths of the Generals could not be separated from the influence of China. Certainly, China was also accused of being involved in the G30S/PKI, which resulted in the severance of diplomatic relations in the early days of the New Order. This party was finally banned by Pangkopkamtib Soeharto on March 12, 1966. The Presidential Decree No. 1/3/1966 regarding the Dismissal of the Indonesian Communist Party, it contained the dissolution of PKI, including its organizational parts from the central level down to the regions along with all other organizations that were of the same class, took shelter, and took shelter under it. Based on the results of the investigation, as well as the decision of the Extraordinary Military Court against PKI figures, they were accused of being involved in the events of the 30 September Movement. ${ }^{5}$

To manage land and buildings whose owners are no longer known, the letter of the Minister of Finance No.S394/MK.03/1989 dated 12 April 1989 concerning the instructions for the settlement of former Chinese foreignowned assets. In the attachment to the Minister of Finance letter, there is a statement column that it is resolved by

1 Edy Hadyanto, chairman, the Association of Indonesian Money Transfer Organizers, Participants of the Indonesian BHP Meeting in Bintaro, 20-22 October 2019.

2 Chapter V, the Conclusion, Article 12, the Presidential Decree No. 10 of 1959, held on 16-11-1959, Junior Minister of Justice, Sahardjo.

3 The Minister of Trade at that time was held by Rachmat Mujomisero in the Karya Cabinet government or also known as the Djuanda Cabinet.

$4 \mathrm{http} / / /$ bursa-kerja.ptkpt.net/id4/112-1/Peraturan-Pemerintah-Nomor-10-Tahun-1959_100081_trianandra_bursa-kerjaptkpt.html accessed on 7 October 2019

5 Kompas. Soeharto Bubarkan PKI". https://nasional.kompas.com/read/2016/03/12/ 06310001/12.Maret.1966. Soeharto.Bubarkan.PKI?page=all. Author: Kristian Erdianto. (online) Accessed on 7 October 2019. 
afwezigheid.

It is very interesting that the Minister of Finance is very intensely spent only to settle Chinese assets. However, after careful examination, it turns out that PMK has undergone revision or amendment 4 (four) times for reasons of improvement. However, when improvements were made starting with PMK 188, PMK 154 and finally in 2015 with PMK No. 31, changing a very important part according to law, by eliminating the way of settlement through afweziheid. This means that the three PMK no longer use afwezigheid.

Researchers are very respectful if PMK still uses the solution of afwezigheid. This PMK has been challenged a lot, if we look closely at the parties, the plaintiffs can have their claims granted, ${ }^{1}$ for example in Tanjungpadang the ruling of the District Court Decision No: 20 / Pdt.G / 2012 / PN.Tdn dated October 3, 2013, although it ended in the Supreme Court, the petition was finally rejected.

However, in the settlement of the Ex-Chinese Foreign Owned Assets/Chinese (ABMAC/T) at the Directorate General of State Assets, the Ministry of Finance does not go through afwezigheid anymore. In fact, the support for the determination of afwezigheid will guarantee legal certainty, especially for the new owners. According to Justicio Engko, ${ }^{2}$ afwezigheid is only used for individuals as regulated in the B.W. not for legal entities. Chinese assets managed by the Ministry of Finance, Directorate General of State Assets, are assets of organizations or associations that have assets such as school buildings. According to the researcher, this statement is interesting, because in fact ABMAC/T, both Chinese or its associations and individuals are treated the same in its completion. Furthermore, Justicio Engko explained, there are indeed some that belong to individuals, but because of the Minister of Finance's Letter No. S-394 /MK.03/1989 has been updated with the enactment of the PMK. 188 to PMK No. 31 / PMK.06 / 2015, of course individual settlement no longer uses the determination of afwezigheid, but it is resolved by Tim Interdep. ${ }^{3}$

However, when viewed in terms of hierarchy, the informants also admitted that there were irregularities in PMK because it was not in sync with other regulations, namely B.W. This PMK, never carried out a judicial review, and this PMK is still legally implemented until there is a new regulation. The informant did not know for sure why PMK was completed 3 (three) times and did not mention afwezigheid.

According to the researcher, the management of China' asset settlement started from the letter of the Minister of Finance No. S-394 /MK.03/1989. In the attachment to the Letter of the Minister of Finance, it is known that China' asset data is well-structured with the columns includes Name, Location, Type of Asset and Remark. In the description column it is stated, resolved by afwezigheid.

The solution by use afwezigheid is very appropriate, meaning that with a court decision, it will be lawful and binding on interested parties. If in the future there is a lawsuit, of course, the correction will also be legal. This letter was issued due to political pressure by the authorities on the ethnic Chinese, so that in order to strengthen or clarify the legal status, the role of the court in determining as an afwezigheid is appropriate in the interests of the law.

The Minister' letter was then refined with the enactment of PMK 188. In his consideration that in an effort to create legal certainty, the procedures for handling the settlement of foreign/Chinese assets which have been referring to the letter of the Minister of Finance No. S-394/MK.3/1989 need to be reviewed back to be refined and upgraded to the regulation of the Minister of Finance. When improvements are made, the point is only to increase the status of a Ministerial Letter to a Ministerial Regulation, but the solution is no longer through afwezigheid but is resolved by forming a Central Settlement Team (Tim Penyelesaian Pusat). ${ }^{4}$

When stipulated PMK No.154 / PMK.06 / 2011 in considering, that in order to optimize the management of ExChinese Foreign Assets in an orderly, directed, and accountable manner, it was necessary to make improvements to the Regulation of the Minister of Finance as improvements were made, among others adding to the legal basis in controlling Chinese assets that will be controlled by the State, how to estimate if there are new buildings, the force majeure if the installments have not been completed and so on. However, these improvements do not regulate if the Chinese assets are in an afwezigheid state.

In 2015, the Minister of Finance stipulated PMK No. 31 / PMK.06 / 2015, in considering, that in order to settle

1 Gatra. http://arsip.gatra.com/2007-01-10/majalah/artikel.php?pil=23\&id=101331 (online) accessed on 7 October 2019.

2 Justicio Engko is a State Civil Servant at the Directorate of State Assets, Ministry of Finance

3 The Interdepth Team is a team formed by the Minister of Finance. This team consists of members from various elements of the Ministry / Institution, which is determined by a Decree.

4 Membership of the Settlement Team as referred to in paragraph (1) consists of elements from central level agencies, including: Ministry of Finance, Ministry of Law and Human Rights; Ministry of Defense; Ministry of Education; State Intelligence Agency; National Land Agency; Attorney General' Office; and the Indonesian Police. 
Ex-Chinese Owned Assets that are more optimal, orderly, directed, accountable, thorough and comprehensive and to further realize legal certainty in the status of asset ownership and/or the maximum welfare the people, so that Regulation of the Minister of Finance No. 188 / PMK.06 / 2008 concerning Settlement of Former Foreign/ChineseOwned Assets as amended by Regulation of the Minister of Finance No. 154 / PMK.06 / 2011 needs to be improved.

As a result of politics, Chinese land and buildings fell to the country. This is really concerning. Certainly, when a Chinese association is in the form of a school or hospital, it must have a permit for its establishment, both a business permit and a building use right. If the owner of a business permit is deemed to have committed treason, then the owner is responsible for his actions, namely being punished. However, their civil rights should be protected by the state, not being taken from their property and controlled directly by the state. Of course, criminal and civil acts must be distinguished, which may not have a relationship with a criminal act.

When the owner filed a lawsuit with the court, the judges used the current context that Eigendom was not converted into property rights as regulated in the UUPA. The right to use land has expired. Land certificates are still verponding, because land is not converted, it falls to the State. The judges should have thought at that time, what happened, not using the present context, which is in line with teleological interpretation, namely interpretation with due regard to the intent and purpose of the law. ${ }^{1}$ The needs change over time, while the law remains the same which emphasizes compensation, when land will be transferred to a social function or public interest.

If this PMK is viewed from a hierarchical point of view, then this PMK does not have a strong basis for the law above it or B.W how to manage absenteeism assets. Therefore, it is very reasonable if the Chinese assets, whose whereabouts are no longer known, must be represented by absent person, to guarantee legal certainty. When these assets are released to the public or legal entities which are also known as third parties, the third party must pay compensation to the State. The term compensation seems less precise because the asset is not under the Directorate of State Assets, it should be a sale and purchase. China's assets should be in ATR/BPN on the grounds that the core service of ATR/BPN is more precise and suitable, because land data is already in BPN and when ATR/BPN finds assets of absenteeism, then according to the provisions of ATR/BPN, they definitely need legal certainty from the court, namely the determination of absenteeism. Between ATR/BPN and BHP can work together to resolve land owners whose whereabouts and heirs are unknown.

As described above, it can be seen that to own the property of the absent person, it is not necessarily owned when its absence is known, but there is a mechanism provided by law, namely the request of the interested parties to court at the residence of the absent person based on a court order or order based on applicable regulations. This is useful as legal protection for the absent person and legal certainty for the parties, including the absent person.

\section{Concept and Practice of Absenteeism: A Comparative Study of Indonesia and the Dutch}

There are 3 (three) legal systems in effect in Indonesia. The comparisons made were B.W which applies in Indonesia and NBW which applies in the Dutch. In fact, the Indonesian legal system B.W has similarities to the Dutch legal system NBW. This is because the legal system developed in Indonesia originates from the Dutch with a concordance principle. Indonesia and the Dutch adhere to the Continental European or civil law system which is characterized by abstract, conceptual, systemic, and deductive, tend to plan, systematize and organize comprehensively. ${ }^{2}$ The civil law system is widely adopted in European countries. This system is also called Roman law because it originated in Rome, during the reign of Emperor Yustianus. Laws are systematically compiled in written form, formed by authorized institutions, with the main objective of legal certainty. Law is always identified with written laws or regulations that govern all human behavior.

\subsection{Regulation in Indonesia}

In Indonesia based on B.W with 4 books, ${ }^{3}$ as promulgated in Staatsbald 1847 No. 23 and declared effective on May 1, 1848. ${ }^{4}$ The institution appointed to take care of absences was the Heritage Hall (Balai Harta Peninggalan). The institution that is now under the Directorate General of Law of the Ministry of Law and Human Rights of the Republic of Indonesia, which was previously the Ministry of Justice. BHP and BW are Dutch heritage institutions that are still in effect today based on the transitional rules of the 1945 NRI Constitution. BW still occupies the National Law System, although the existence of BW has received criticism that BW is no longer a law (wet) but only a legal guideline. Apart from the pros and cons, the cons are still using B.W as civil law traffic. B.W and BHP

1 Chainur, A, (2000). Dasar-Dasar Ilmu Hukum, Jakarta: Sinar Grafika, p. 92

2 Wartiningsih, et,. all., Loc.,Cit., p. 6.

3 Book I about people, Book II about objects, Book III about bonds and Book IV about proof and expiration.

4 Syahrizal, D. (2011). Kasus-kasus Hukum Perdata Di Indonesia, Yogyakarta: Pustaka Grhatama, p. 21 
are two still recognized institutions. One of the duties and functions (tusi) of $\mathrm{BHP}^{1}$ still follows the authorities regulated in B.W namely managing absent assets as referred to in Article 463 B.W based on a court decision, and other authorities based on Article $418 .^{2}$

In the case of absenteeism, there is no control to determine someone explicitly about absenteeism, because the initiative always comes from the interested parties. When an individual leaves his/her residence there is no obligation to report his land and building to the local government, except to report himself to move, so that a building can become slum and become a source of disease or the land becomes abandoned. Even though there is a possibility that the power is left behind, this power may no longer be valid, so that the management of the interests of an individual leaving his place of residence can become neglected. Absence arrangement must pay attention to the domicile that is left behind, there is no 5 year power of attorney, if there is 10 year power to confirm the alleged death and 30 years expiration.

\subsection{Regulation in the Dutch}

The development of Dutch' civil law (Nieuw Burgerlijk Wetboek) NBW since 1992 has grown to 10 books. This shows that civil rights are integrated into a book, as a collection of various civil rights provisions. Codification is still maintained to facilitate access to the law rather than the provisions being scattered in various laws.

The rules of absenteeism were still maintained, but it was no longer implemented by Weskamer institution, but by a court-appointed legal administrator. Every individual who will leave his/her residence for a long period of time must be able to report to the local government $(1: 11 \mathrm{NBW})$ because he/she can lose his/her residence. Therefore, if he wants to leave the residence, he/she can appoint a legal administrator appointed by the court or interested parties or the prosecutor can submit to the court to appoint an administrator to represent the absent person (1:409).

Because NBW no longer regulates the power left by the absent person, it is expressly stated that a person who leaves his place of residence is equated with a person whose existence is uncertain (1:409:2). (Book 1 Article 409 Paragraph 2) the management of a legal administrator ends when a) there is a joint decision, b) administrator dismissed and c) the death of the property owner is determined (1:411). In order to secure the property of the absent person, the property record, original or authentic copy of the absent person is registered at the hearing (1:419).

Thus, the similarity in regulating absenteeism between Indonesia and the Dutch is both determined based on a court order. Before there is news about the life or death of an individual, the person who is not present can be summoned in court. The place of residence is used as an indicator to determine whether a person is in a state of absence and suspected death if he leaves his/her residence for 5 years.

The difference is that Indonesia still knows the authority or power for 10 years, while the Dutch does not know the power anymore. The institution that handles absenteeism in Indonesia is BHP, whereas in the Dutch is the legal administrator who can take the initiative to manage the assets of the absent person and represent the absent person.

\section{Conclusion}

The essence of absenteeism (absentee dominii) is a guarantee of legal protection certainty against the inability of legal subjects to attend when expected. Legal protection certainty can occur because of the presence of representatives based on court decisions. The implementation of absenteeism regulations includes regulations that are not in sync with higher regulations, namely, the regulation of the Minister of Finance (PMK) on the settlement of Chinese foreign assets. This PMK is still implemented by taking advantage of the unsynchronized regulations. There are also regulations which are equivalent but can be implemented by applying the legal principle lex specialis derogat legi generali. The management of ideal absenteeism is Balai Harta Peninggalan (BHP), as it acts as organizer, defends the interests of the absentee, and acts as a representative for the absent person. The management of absenteeism is carried out through publicity and supervision carried out by the Attorney General, BPK and tiered supervision within the Ministry of Law and Human Rights of the Republic of Indonesia. Management until the 30-year expiration period is a form of legal protection for civil rights for absentees.

1 Duties and Functions of BHP: Article 366 supervisory guardian, Article 449 supervisory officer, absent property manager Article 463, unmanaged property manager Article 1126-1129.

2 The Heritage Hall and the trusteeship council cannot be ruled out and any interference, which is ordered to them according to the provisions of the law. All actions and agreements that are contrary to the above provisions are null and void. 


\section{References}

Bakker, L., \& Moniaga, S. (2010). The space between: Land claims and the law in Indonesia. Asian Journal of Social Science, 38(2), 187-203.

Chainur, A, (2000). Dasar-Dasar Ilmu Hukum, Jakarta: Sinar Grafika.

CNN Indonesia, “Uang Elektronik Hilang, Dana Tak Bisa Kembali” (on line) accessed on 18 December 2018.

Fuady, M. (2013). Teori-Teori Besar Dalam Hukum (Grand Theory), Jakarta: Prenadamedia Group.

Garner, B.A. (2009). Black's Law Dictionary, ST. Paul: West Group.

Gatra. http://arsip.gatra.com/2007-01-10/majalah/artikel.php?pil=23\&id=101331 (online) accessed on 7 October 2019.

Ilyas A. et al. (2006). Kumpulan asas-asas hukum, Jakarta: PT. RajaGrafindo Persada.

Irwansyah. (2020). Kajian Ilmu Hukum, Yogyakarta: Mirra Buana Media.

Kalimantan Bisnis.Com, 02 Februari 2018 02:00 WIB, “Duit Tak Bertuan, Mau Diapakan?”, (on line) accessed on 25 September 2018.

Kompas. Soeharto Bubarkan PKI". https://nasional.kompas.com/read/2016/03/12/ 06310001/12.Maret.1966. Soeharto.Bubarkan.PKI?page=all. Author: Kristian Erdianto. (online) Accessed on 7 October 2019.

Krishna, V. V., Kubitza, C., Pascual, U., \& Qaim, M. (2017). Land markets, property rights, and deforestation: insights from Indonesia. Journal World Development, Vol. 99, 335-349.

Liputan 6, "Uang Tak Bertuan Bisa Disita Negara", (on line) accessed on 24 September 2018.

Marzuki, P.M. (2011). Penelitian Hukum, Jakarta: Kencana Prenada Media Group.

Nugroho, B.D. (2017). Hukum Perdata Indonesia, Integrasi Hukum Eropa Kontinental Ke Dalam Sistem Hukum Adat dan Nasional, Bandung: PT Refika Aditama.

Sofwan, S.S.M. (2008). Hukum Perdata: Hukum Benda, Yogyakarta, Liberty, p.24

Sri Susyanti Nur, (2015). Aspek Hukum Pendaftaran Tanah Bekas Milik Asing sebagai Aset Pemerintah Daerah. Hasanuddin Law Review, 1(1), 87-100. doi: http://dx.doi.org/10.20956/halrev.v1i1.42.

Syahrizal, D. (2011). Kasus-kasus Hukum Perdata Di Indonesia, Yogyakarta: Pustaka Grahatama. 